\title{
Coupling of Carbomethoxy and Vinylidene Ligand in Molybdenum Complexes
}

\author{
J ung-Yen Yang, Shou-Ling Huang, Ying-Chih Lin,* Yi-Hong Liu, and Yu Wang \\ Department of Chemistry, National Taiwan University, Taipe, Taiwan, 106 Republic of China
}

Received September 13, 1999

\begin{abstract}
Treatment of $\left[\mathrm{Cp}\right.$ (dppe) $\left.(\mathrm{CO}) \mathrm{Mo}=\mathrm{C}=\mathrm{C}(\mathrm{Ph}) \mathrm{CH}_{2} \mathrm{CH}=\mathrm{CH}_{2}\right]$ (2) with MeONa caused nucleophilic attack to occur at the terminal $\mathrm{CO}$ ligand. This is followed by a coupling reaction of the resulting carbomethoxy group with $\mathrm{C} \alpha$ of the vinylidene ligand accompanied with coordination of the terminal ol efin to afford $\mathrm{Cp}(\mathrm{dppe}) \mathrm{MoC}(\mathrm{COOMe})=\mathrm{C}(\mathrm{Ph}) \mathrm{CH}_{2} \mathrm{CH}=\mathrm{CH}_{2}$ (5). Similar coupling was observed when $\left[\mathrm{Cp}(\mathrm{dppe})(\mathrm{CO}) \mathrm{Mo}=\mathrm{C}=\mathrm{C}(\mathrm{Ph}) \mathrm{CH}_{2} \mathrm{Ph}\right] \mathrm{l}$ (3) was treated with $\mathrm{MeONa}$, but the reaction afforded the neutral allylic complex $\mathrm{Cp}(\mathrm{dppe}) \mathrm{Mo}[\mathrm{CH}-$ (COOMe)C(Ph)CHPh] (6). The structures of complexes $\mathbf{5}$ and $\mathbf{6}$ have been determined by $\mathrm{X}$-ray diffraction analysis.
\end{abstract}

\section{Introduction}

We previously described a new type of deprotonation reaction of several cationic vinylidene complexes leading to a rare class of metal complexes containing various cyclic ligands. ${ }^{1}$ Using this synthetic strategy, we successfully prepared several ruthenium cyclopropenyl complexes containing various substituents as well as ruthenium furanyl complexes. For the cyclopropenyl complex, the cyclization reaction also results in formation of a chiral carbon center in the three-membered ring. These features render this cyclization process potentially useful for organic synthesis. ${ }^{2}$ Therefore, we set out to study the chemical reactivity of a molybdenum vinylidene system of $\mathrm{Cp}\left(\mathrm{Ph}_{2} \mathrm{PCH}_{2} \mathrm{CH}_{2} \mathrm{PPh}_{2}\right)(\mathrm{CO}) \mathrm{Mo}^{3}$ Such a system was chosen because the presence of donor phosphine ligands is known to assist the preparation of cationic metal vinylidene complexes, ${ }^{4}$ and the presence of a CO ligand could be utilized to study carboncarbon bond formation. Surprisingly, treatment of these vinylidene complexes containing a terminal CO ligand with sodium methoxide affords unexpected products via an unprecedented coupling of a carbomethoxy group with $\mathrm{C} \alpha$ of the vinylidene ligand. ${ }^{5}$ Coupling reactions

(1) (a) Ting, P. C.; Lin, Y. C.; Cheng, M. C.; Wang, Y. Organome tallics 1994, 13, 2150. (b) Ting, P. C.; Lin, Y. C.; Lee, G. H.; Cheng, M. C.; Wang, Y. J . Am. Chem. Soc. 1996, 118, 6443. (c) Chang, C. W.; Ting, P. C.; Lin, Y. C.; Lee, G. H.; Wang, Y.J J Organomet. Chem. 1998, 553, 417. (d) Lo, Y. H.; Lin, Y. C.; Lee, G. H.; Wang, Y. Organometallics 1999, 18, 982.

(2) (a) Kubota, K.; Mori, S.; Nakamura, M.; Nakamura, E. J . Am. Chem. Soc. 1998, 120, 13334. (b) Muller, P.; Imogai, H. Tetrahedron: Asymmetry 1998, 9, 4419. (c) Plemenkov, V. V.; Rul, S. V.; Gubaidullin, A. T.; Litvinov, I. A.; Karaseva, I. P.; Nuretdinov, I. A. Russ. J . Org. Chem. 1998, 34, 971.

(3) (a) Allen, S. R.; Beevor, R. G.; Green, M.; Norman, N. C.; Orpen, A. G.; Williams, I. D. J . Chem. Soc., Dalton Trans. 1985, 435. (b) Beevor, R. G.; Green, M.; Orpen, A. G.; Williams, I. D. J . Chem. Soc., Dalton Trans. 1987, 1319. (c) Nickias, P. N.; Seleague, J. P.; Young, B. A. Organometallics 1988, 7, 2248. (d) Chang, K. H.; Lin, Y. C. Chem. Commun. 1998, 1441.

(4) (a) Bruce, M. I. Chem. Rev. 1991, 91, 197. (b) Bruce, M. I.; Swincer, A. G. Adv. Organomet. Chem. 1982, 20, 159.

(5) (a) Buil, M. L.; Esteruelas, M. A.; Lòpez, A. M.; Oñate, E. Organometallics 1997, 16, 3169. (b) Bianchini, C.; Casares, J. A.; Peruzzini, M.; Romerosa, A.; Zanobini, F. J . Am. Chem. Soc. 1996, 118 , 4585. (c) Faure, M.; Maurette, L., Donnadieu, B.; Lavigne, G. Angew. Chem., Int. Ed. Engl. 1999, 34, 518. involving $\mathrm{C} \alpha$ of a vinylidene ligand on the metal complex are limited in the literature. Herein we report preparation of a number of cationic molybdenum vinylidene complexes $\mathrm{Cp}\left(\mathrm{Ph}_{2} \mathrm{PCH}_{2} \mathrm{CH}_{2} \mathrm{PPh}_{2}\right)(\mathrm{CO}) \mathrm{Mo}=\mathrm{C}=\mathrm{C}(\mathrm{Ph})$ $\mathrm{CH}_{2} \mathrm{R}$ and nucleophilic addition of methoxide to the $\mathrm{CO}$ ligand followed by a coupling reaction leading to carboncarbon formation at $\mathrm{C} \alpha$ of the vinylidene ligand.

\section{Results and Discussion}

Preparation of the Acetylide Complex 1. The acetylide complex $[\mathrm{Mo}](\mathrm{CO}) \mathrm{C} \equiv \mathrm{CPh} \quad\left(\mathbf{1},[\mathrm{Mo}]=\left(\eta^{5}-\right.\right.$ $\mathrm{C}_{5} \mathrm{H}_{5}$ )(dppe)Mo, dppe $=\mathrm{Ph}_{2} \mathrm{PCH}_{2} \mathrm{CH}_{2} \mathrm{PPh}_{2}$ ) was prepared by two different methods. The reaction of [Mo](CO)Cl with LiCCPh in THF, which gave 1 in reasonable yield, required handling of an air-sensitive lithium reagent. We therefore pursued an alternative synthesis, namely, the reaction of $[\mathrm{Mo}](\mathrm{CO}) \mathrm{Cl}$ with $\mathrm{HC} \equiv \mathrm{CPh}$. This reaction gave $\{[\mathrm{Mo}](\mathrm{CO})=\mathrm{C}=\mathrm{CHPh}\} \mathrm{Cl}$, which underwent thermal decarbonylation to afford $\left\{[\mathrm{Mo}]\left(\eta^{2}-\mathrm{HC} \equiv\right.\right.$ $\mathrm{CPh})\} \mathrm{Cl}$. Then the $\eta^{2}$-phenylacetylene complex was treated with $\mathrm{CO}$ in the presence of $\mathrm{MeONa}$ to give $\mathbf{1}$. The tautomerization of alkyne to vinylidene on the bisdimethyl phenyl phosphine molybdenum analogue has been reported before. ${ }^{3 c}$ Our scheme involves more steps but gives higher overall yield.

The ${ }^{31 P}$ NMR spectrum of $\mathbf{1}$ exhibits two sets of doublet resonances at $\delta 90.4$ and 78.7 with J p-p $=37.2$ $\mathrm{Hz}$. In the ${ }^{1} \mathrm{H}$ NMR spectrum, the resonance for the $\mathrm{Cp}$ ligand is a doublet at $\delta 4.49$ with $\mathrm{J} \mathrm{H}-\mathrm{P}=1.6 \mathrm{~Hz}$, indicating coupling with only one of the phosphorus atoms of the dppe. In the ${ }^{13} \mathrm{C}$ NMR spectrum, the signal for the terminal CO ligand is also a doublet at $\delta 245.0$

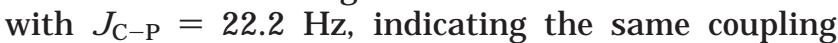
pattern. By the use of selective heteronuclear decoupling techniques, i.e., ${ }^{1} \mathrm{H}\left\{{ }^{31} \mathrm{P}\right\}$ and ${ }^{13} \mathrm{C}\left\{{ }^{31} \mathrm{P}\right\}$ NMR spectra, we are able to determine that both ${ }^{1} \mathrm{H}-{ }^{31} \mathrm{P}$ coupling of the $\mathrm{Cp}$ ligand and ${ }^{13} \mathrm{C}-{ }^{31} \mathrm{p}$ coupling of the $\mathrm{CO}$ ligand originate from the same phosphorus atom displaying the downfield resonance (at $\delta$ 90.4) in the ${ }^{31 P}$ NMR spectrum. Coupling between carbon and phosphorus nuclei of the complex with a piano-stool coordination geometry 
Scheme 1
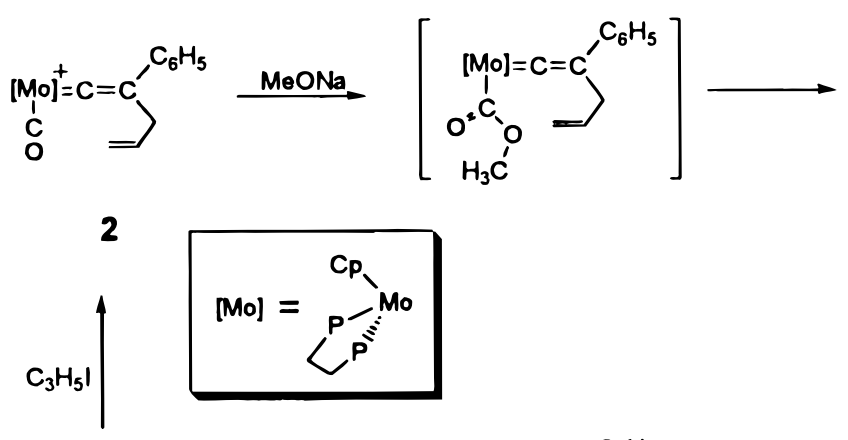

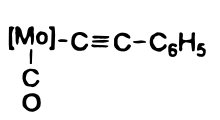

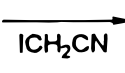

1<smiles>O=[W](O)[C@H](Cc1ccccc1)C(Cc1ccccc1)Cc1ccccc1</smiles>

3

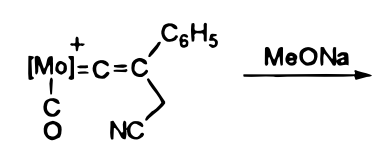
4

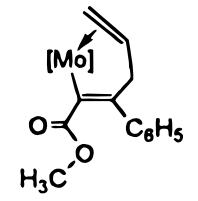

5

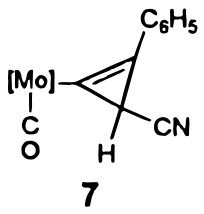<smiles>COC(=O)C(C)C(Cc1ccccc1)C(C)(C)C</smiles>

depends on the orientation. ${ }^{6}$ In the ${ }^{1} \mathrm{H}$ NMR spectrum of $\left\{[\mathrm{Mo}]\left(\eta^{2}-\mathrm{HC} \equiv \mathrm{CPh}\right)\right\} \mathrm{Cl}$, the characteristic triplet resonance at $\delta 10.02$ with $\mathrm{J} \mathrm{H}-\mathrm{P}=13.8 \mathrm{~Hz}$ is assigned to the terminal $\mathrm{CH}$. The corresponding ${ }^{1} \mathrm{H}$ signal of the vinylidene proton of $\{[\mathrm{Mo}](\mathrm{CO})=\mathrm{C}=\mathrm{CHPh}\} \mathrm{Cl}$ appears as a singlet at $\delta 4.78$.

Preparation of Vinylidene Complexes. Treatment of 1 with $\mathrm{BrCH}_{2} \mathrm{R}\left(\mathrm{R}=\mathrm{CH}=\mathrm{CH}_{2}, \mathrm{C}_{6} \mathrm{H}_{5}\right.$, and $\left.\mathrm{CN}\right)$ afforded cationic brown-red vinylidene complexes $\{[\mathrm{Mo}$ ]$\left.(\mathrm{CO})=\mathrm{C}=\mathrm{C}(\mathrm{Ph}) \mathrm{CH}_{2} \mathrm{R}\right\} \mathrm{Br}\left(\mathbf{2}, \mathrm{R}=\mathrm{CH}=\mathrm{CH}_{2} ; \mathbf{3}, \mathrm{R}=\mathrm{C}_{6} \mathrm{H}_{5}\right.$; 4, $\mathrm{R}=\mathrm{CN}$ ). All reactions gave the desired products in $70-80 \%$ yields. Use of organic iodi des gave lower yields. All these vinylidene complexes are soluble in $\mathrm{CHCl}_{3}$, $\mathrm{CH}_{2} \mathrm{Cl}_{2}$, and $\mathrm{CH}_{3} \mathrm{OH}$ but are insoluble in hexane. Complex $\mathbf{2}$ is air- and moisture-sensitive but is stable under nitrogen. The ${ }^{1} \mathrm{H}$ NMR spectrum of $\mathbf{2}$ displays multiplet resonances centered at $\delta 5.00,4.96$ and 2.87, 2.78 assignable to the olefinic and saturated diastereotopic $\mathrm{CH}_{2}$ units, respectively, and the multiplet resonance at $\delta 5.62$ to the allylic $\mathrm{CH}$ unit. The geminal coupling constant of the diastereotopic methylene protons is $15.6 \mathrm{~Hz}$, and interestingly, the long-range $\mathrm{P}-\mathrm{H}$ coupling with one of the phosphorus atoms (5 $\mathrm{J} \mathrm{P}-\mathrm{H}=2.8$ and $2.0 \mathrm{~Hz}$ ) is also observed for these protons. The ${ }^{1} \mathrm{H}$ NMR spectra of complexes $\mathbf{3}$ and $\mathbf{4}$ display the same features. In the ${ }^{13} \mathrm{C}$ NMR spectrum, the characteristic doublet of doublet resonance centered at $\delta 358.4$ with ${ }^{2} \mathrm{~J} \mathrm{p}-\mathrm{C}=36.0$ and $6.5 \mathrm{~Hz}$ is assigned to the vinylidene $\mathrm{C} \alpha$. In the ${ }^{31} \mathrm{P}$ NMR spectrum, two doublet resonances at $\delta 71.5$ and 67.0 with $J_{\mathrm{p}-\mathrm{p}}=37.5 \mathrm{~Hz}$ are assigned to the dppe ligand. In the ${ }^{31 P}$ NMR spectra of $\mathbf{3}$ and $\mathbf{4}$, the ${ }^{31} \mathrm{P}$ resonances fall in a similar region with comparable coupling constants $(\delta 69.0$ and 66.2 with J $\mathrm{p}-\mathrm{p}=36.3$

(6) (a) Bainbridge, A.; Craig, P. J .; Green, M. J . Chem. Soc. (A) 1968 2713. (b) Faller, J. W.; Anderson, A. S. J . Am. Chem. Soc. 1970, 92 , 5852. (c) Beach, D. L.; Barnett, K. W. J . Organomet. Chem. 1975, 97, C27. (d) Sakaba, H.; Ishida, K.; Horino, H. Chem. Lett. 1995, 1145.
$\mathrm{Hz}$ for 3 and $\delta 66.8$ and 63.7 with J p-p $=30.7 \mathrm{~Hz}$ for 4). Other spectroscopic features are consistent with their formulations.

Reactions of 2 and 3 with MeONa. Having established the cyclopropenation reaction of several cationic vinylidene complexes of ruthenium, we examined the deprotonation reaction of the molybdenum complex $\mathbf{2}$ using various bases with an expectation to see similar results. However, much to our surprise, treatment of $\mathbf{2}$ with $\mathrm{n}-\mathrm{Bu}_{4} \mathrm{NOH}, \mathrm{DBU}$, and $\mathrm{n}-\mathrm{Bu}_{4} \mathrm{NF}$ gave no reaction. In the reaction of $\mathbf{2}$ with $\mathrm{MeONa}$ the coupling product $[\mathrm{Mo}]\left(\eta^{3}-\mathrm{C}(\mathrm{COOMe})=\mathrm{C}(\mathrm{Ph}) \mathrm{CH}_{2} \mathrm{CH}=\mathrm{CH}_{2}\right)$ (5) (Scheme 1) was obtained in high yield. Formation of $\mathbf{5}$ is rationalized by nucleophilic addition of $\mathrm{MeO}^{-}$to the terminal CO ligand ${ }^{7}$ giving the carbomethoxy group followed by a coupling reaction ${ }^{8}$ of the carboxymethoxy group with $\mathrm{C} \alpha$ of the vinylidene ligand to afford $\mathbf{5}$ (Scheme 1) in high yield. The terminal olefin group, acting as a twoelectron donor, fills the vacant site left from the coupling reaction. It is interesting to note the difference in spectral characteristics of $\mathbf{2}$ and $\mathbf{5}$. Signals of the terminal vinyl group in the ${ }^{1} \mathrm{H}$ NMR spectrum of $\mathbf{2}$ appear at $\delta 5.62(=\mathrm{CH})$ and $5.00,4.96\left(=\mathrm{CH}_{2}\right)$, while those of 5 occur at $\delta 1.78(=\mathrm{CH})$ and 2.58, $3.66\left(=\mathrm{CH}_{2}\right)$. These assignments are determined by the use of 2D COSY and HSQC experiments. While most of $\mathrm{H}-\mathrm{H}$

(7) (a) Nakazawa, H.; Kadoi, Y.; Mizuta, T.; Miyoshi, K.; Yoneda, H. J Organomet. Chem. 1989, 366, 333. (b) Gibson, D. H.; Ong, T. S.; Ye, M.; Franco, J. O.; Owens, K. Organometallics 1988, 7, 2569. (c) Busetto, L. L.; Zanotti, V.; Norfo, L.; Palazzi, A.; Albano, V. G.; Braga, D. Organometallics 1993, 12, 190. (d) Nakazawa, H.; Yamaguchi, M.; Kubo, K.; Miyoshi, K.J Organomet. Chem. 1992, 428, 145. (e) Werner, H.; Hofmann, L.; Zolk, R. Chem. Ber. 1987, 120, 379. (f) Kiel, W. A. Buhro, W. E.; Gladysz, J. A. Organometallics 1984, 3, 879. (g) Carlos, F.; Barrientos-Penna, A.; Hugo, K. O.; Derek, S. Organometallics 1985, 4, 367. (h) Bao, Q. B.; Rheingold, A. L.; Brill, T. B. Organometallics 1986, 5, 2259.

(8) (a) Wiedemann, R.; Steinert, P.; Gevert, O.; Werner, H. J . Am. Chem. Soc. 1996, 118, 2495. (b) Braun, T.; Meuer, P.; Werner, H. Organometallics 1996, 15, 4075. 


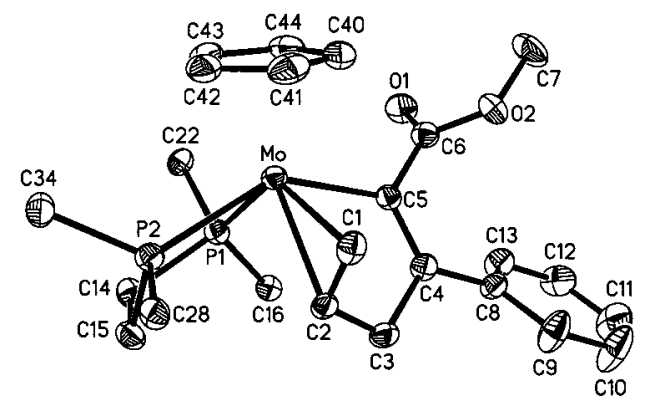

Figure 1. ORTEP drawing of $\mathbf{5}$ with thermal ellipsoids shown at the $30 \%$ probability level. For the dppe phenyl groups, only the ipso carbons are shown.

\begin{tabular}{|c|c|c|c|}
\hline \multicolumn{4}{|c|}{$\mathrm{p}(\mathrm{dppe}) \mathrm{MoC}(\mathrm{COOMe})=\mathrm{C}(\mathrm{Ph}) \mathrm{CH}_{2} \mathrm{CH}=\mathrm{CH}_{2}($} \\
\hline $\begin{array}{l}\text { Mo-P1 } \\
\text { Mo-P2 } \\
\text { Mo-C1 } \\
\text { Mo-C2 } \\
\text { Mo-C5 } \\
\text { P1-C14 } \\
\text { P1-C16 } \\
\text { P1-C22 } \\
\text { P2-C15 } \\
\text { P2-C28 } \\
\text { P2-C34 } \\
\text { O1-C6 } \\
\text { O2-C6 } \\
\text { O2-C7 } \\
\text { C1-C2 } \\
\text { C2-C3 }\end{array}$ & $\begin{array}{l}2.4844(11) \\
2.4794(11) \\
2.216(3) \\
2.295(3) \\
2.248(3) \\
1.855(4) \\
1.842(4) \\
1.841(4) \\
1.829(4) \\
1.824(4) \\
1.844(4) \\
1.199(5) \\
1.355(4) \\
1.433(5) \\
1.406(5) \\
1.503(5)\end{array}$ & $\begin{array}{l}\text { C3-C4 } \\
\text { C4-C5 } \\
\text { C4-C8 } \\
\text { C5-C6 } \\
\text { C8-C9 } \\
\text { C8-C13 } \\
\text { C9-C10 } \\
\text { C10-C11 } \\
\text { C11-C12 } \\
\text { C12-C13 } \\
\text { C14-C15 } \\
\text { C40-C41 } \\
\text { C40-C44 } \\
\text { C41-C42 } \\
\text { C42-C43 } \\
\text { C43-C44 }\end{array}$ & $\begin{array}{l}1.494(5) \\
1.338(5) \\
1.493(5) \\
1.473(5) \\
1.383(5) \\
1.380(5) \\
1.382(6) \\
1.367(7) \\
1.345(7) \\
1.383(6) \\
1.521(5) \\
1.400(6) \\
1.413(6) \\
1.380(6) \\
1.401(6) \\
1.395(6)\end{array}$ \\
\hline $\begin{array}{l}\mathrm{P} 1-\mathrm{Mo}-\mathrm{P} 2 \\
\mathrm{P} 1-\mathrm{Mo}-\mathrm{C} 1 \\
\mathrm{P} 1-\mathrm{Mo}-\mathrm{C} 2 \\
\mathrm{P} 1-\mathrm{Mo}-\mathrm{C} 5 \\
\mathrm{P} 2-\mathrm{Mo}-\mathrm{C} 1 \\
\mathrm{P} 2-\mathrm{Mo}-\mathrm{C} 2 \\
\mathrm{P} 2-\mathrm{Mo}-\mathrm{C} 5 \\
\mathrm{C} 1-\mathrm{Mo}-\mathrm{C} 2 \\
\mathrm{C} 1-\mathrm{Mo}-\mathrm{C} 5 \\
\mathrm{C} 2-\mathrm{Mo}-\mathrm{C} 5 \\
\mathrm{C} 6-\mathrm{O} 2-\mathrm{C} 7 \\
\mathrm{Mo}-\mathrm{C} 1-\mathrm{C} 2 \\
\mathrm{Mo}-\mathrm{C} 2-\mathrm{C} 1\end{array}$ & $\begin{array}{c}77.36(4) \\
126.81(11) \\
90.56(10) \\
83.71(9) \\
86.08(10) \\
74.37(9) \\
140.73(10) \\
36.28(14) \\
78.22(12) \\
71.72(12) \\
115.6(3) \\
74.89(20) \\
68.84(20)\end{array}$ & $\begin{array}{l}\mathrm{Mo}-\mathrm{C} 2-\mathrm{C} 3 \\
\mathrm{C} 1-\mathrm{C} 2-\mathrm{C} 3 \\
\mathrm{C} 2-\mathrm{C} 3-\mathrm{C} 4 \\
\mathrm{C} 3-\mathrm{C} 4-\mathrm{C} 5 \\
\mathrm{C} 3-\mathrm{C} 4-\mathrm{C} 8 \\
\mathrm{C} 5-\mathrm{C} 4-\mathrm{C} 8 \\
\mathrm{Mo}-\mathrm{C} 5-\mathrm{C} 4 \\
\mathrm{Mo}-\mathrm{C} 5-\mathrm{C} 6 \\
\mathrm{C} 4-\mathrm{C} 5-\mathrm{C} 6 \\
\mathrm{O} 1-\mathrm{C} 6-\mathrm{O} 2 \\
\mathrm{O} 1-\mathrm{C} 6-\mathrm{C} 5 \\
\mathrm{O} 2-\mathrm{C} 6-\mathrm{C} 5\end{array}$ & $\begin{array}{l}114.54(22) \\
119.9(3) \\
110.2(3) \\
116.7(3) \\
116.1(3) \\
127.1(3) \\
121.01(25) \\
121.51(24) \\
117.4(3) \\
121.1(3) \\
126.7(3) \\
112.2(3)\end{array}$ \\
\hline
\end{tabular}

coupling constants in the allylic group are measurable for $\mathbf{2}$, only the coupling constant of $17.2 \mathrm{~Hz}$ between mutually trans-protons in the coordinated olefin is attainable for $\mathbf{5}$. However, significant upfield shifts indicate $\pi$-coordination of the terminal double bond in 5. Surprisingly, in the ${ }^{31 P}$ NMR spectrum of $\mathbf{5}$, two singlet resonances at $\delta 90.5$ and 71.2 with equal intensity are observed possibly because of a particular orientation of the dppe ligand. ${ }^{9}$ In the ${ }^{13} \mathrm{C}$ NMR spectrum of $\mathbf{5}$, resonances of $\pi$-coordinated ol efinic carbon atoms appeared at $\delta 60.3(\mathrm{dd})$ and 47.6 (d) with J c-p $=$ $5.4,4.0$, and $5.9 \mathrm{~Hz}$, respectively. To fully characterize this product, single crystals of $\mathbf{5}$ were grown from a hexane/ $\mathrm{CH}_{2} \mathrm{Cl}_{2}$ solution, and the molecular structure was determined by $\mathrm{X}$-ray diffraction analysis. An ORTEP drawing is shown in Figure 1 , and selected bond distances and angles are listed in Table 1. The environment about the metal center corresponds to a structure of distorted four-legged piano-stool geometry. The carbomethoxy group resulting from nucleophilic attack of

(9) Morton, M. S.; Lachicotte, R. J .; Vicic, D. A.; J ones, W. D. Organometallics 1999, 18, 227.

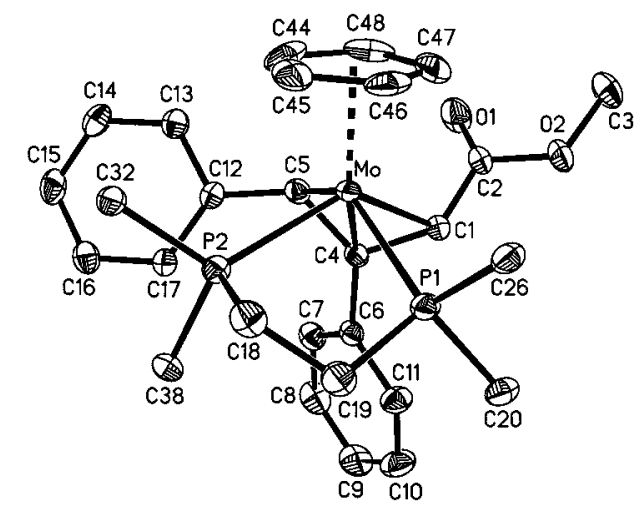

Figure 2. ORTEP drawing of $\mathbf{6}$ with thermal ellipsoids shown at the $30 \%$ probability level. For the dppe phenyl groups, only the ipso carbons are shown.

$\mathrm{MeO}^{-}$to the terminal $\mathrm{CO}$ ligand is bound to $\mathrm{C} \alpha$. And it is clear that the internal olefin $\mathrm{C} 4-\mathrm{C} 5$ is in an $\mathbf{E}$ configuration with the phenyl group and the Mo fragment in a trans disposition. The terminal olefin is oriented such that the $\mathrm{C}=\mathrm{C}$ bond is contained in the plane defined by the metal, the center of the Cp ring, and the trans phosphorus atom. The olefinic ligand coordinates to the metal center with $\mathrm{Mo}-\mathrm{C} 1=2.216$ (3) $\AA$ and Mo-C2 $=2.295$ (3) $\AA$. The Mo-C5 bond length of 2.248(3) $\AA$ is typical of a Mo-C single bond, and the C4-C5 bond length of 1.338(5) $\AA$ typical of a $C=C$ double bond. The $\mathrm{C} 1-\mathrm{C} 2$ bond length of 1.406(5) $\AA$, resulting from coordination to the metal center, is slightly longer that that of the $\mathrm{C} 4-\mathrm{C} 5$ double bond. The $\mathrm{C}=\mathrm{C}$ double bond of 1.437(9) $\AA$ in the cationic olefin complex $\mathrm{Cp}\left[\mathrm{P}_{2}(\mathrm{Me})_{4} \mathrm{C}_{2} \mathrm{H}_{4}\right](\mathrm{CO}) \mathrm{Mo}\left(\mathrm{C}_{2} \mathrm{H}_{3} \mathrm{Ph}\right)^{10}$ is slightly longer possibly due to stronger back-bonding to the antibonding orbital of the ol efin.

Treatment of $\mathbf{3}$ with MeONa similarly causes nucleophilic addition of $\mathrm{MeO}^{-}$to the terminal $\mathrm{CO}$ ligand followed by an analogous coupling reaction and affords the neutral allylic product [Mo][ $\eta^{3}-\mathrm{CH}(\mathrm{COOMe}) \mathrm{C}(\mathrm{Ph})-$ $\mathrm{CHPh]} \mathrm{(6)} \mathrm{in} \mathrm{high} \mathrm{yield.} \mathrm{Due} \mathrm{to} \mathrm{the} \mathrm{lack} \mathrm{of} \mathrm{a} \mathrm{terminal}$ olefin donor group, the vinylideneligand in $\mathbf{3}$ transforms to the $\eta^{3}$-allylic ligand of $\mathbf{6}$ possibly by coupling followed by a 1,3-hydrogen shift. The ${ }^{13} \mathrm{C}$ resonance attributed to the ester carbon appears at $\delta$ 183.2, and $\mathrm{C}-\mathrm{P}$ coupling constants of three multiplet resonances, appearing at $\delta 48.7(\mathrm{~d}), 90.3(\mathrm{t})$, and $49.2(\mathrm{~d})$ with $\mathrm{J} \mathrm{c}-\mathrm{P}=$ 4.5, 3.1, and $2.7 \mathrm{~Hz}$, respectively, clearly indicate the $\eta^{3}$-allylic bonding mode. Two ${ }^{31} \mathrm{P}$ resonances at $\delta 71.3$ and 72.2 with J P-P $=36.8 \mathrm{~Hz}$ are assigned to the dppe ligand.

The structure of 6 has also been confirmed by an $X$-ray diffraction analysis. An ORTEP drawing is shown in Figure 2, and sel ected bond distances and angles are listed in Table 2. The carbomethoxy group is again bound to the allylic terminal carbon. The trisubstituted allylic ligand is in an endo conformation with a synphenyl group and an anti-carbomethoxy group at two terminal carbon atoms. The two allylic $\mathrm{C}-\mathrm{C}$ bond lengths are about equal $(\mathrm{C} 1-\mathrm{C} 4=1.463(4) \AA, \mathrm{C} 4-\mathrm{C} 5$ $=1.446(4) \AA)$, with the Mo-C1 bond slightly shorter

(10) (a) Kegley, S. E.; Bergstrom, D. T.; Crocker, L. S.; Weiss, E. P Berndt, W. G.; Rheingold, A. L. Organometallics 1991, 10, 573. (b) Abugideiri, F.; Kelland, M. A.; Poli, R. Organometallics 1992, 11, 1311. (c) Kegley, S. E.; Walter, K. A.; Bergstrom, D. T.; MacF arland, D. K. Young, B. G.; Rheingold, A. L. Organometallics 1993, 12, 2339. 
Table 2. Selected Bond Distances (Å) and Angles (deg) of Cp(dppe)MoCH(COOMe)C (Ph)CHPh (6)

$\begin{array}{lcll}\text { Mo-P1 } & 2.4992(8) & \text { P2-C38 } & 1.839(3) \\ \text { Mo-P2 } & 2.4951(8) & \text { O1-C2 } & 1.210(4) \\ \text { Mo-C1 } & 2.259(3) & \text { O2-C2 } & 1.376(4) \\ \text { Mo-C4 } & 2.328(3) & \text { O2-C3 } & 1.435(4) \\ \text { Mo-C5 } & 2.324(3) & \text { C1-C2 } & 1.462(4) \\ \text { P1-C19 } & 1.851(4) & \text { C1-C4 } & 1.463(4) \\ \text { P1-C20 } & 1.858(3) & \text { C4-C5 } & 1.446(4) \\ \text { P1-C26 } & 1.858(3) & \text { C4-C6 } & 1.510(4) \\ \text { P2-C18 } & 1.857(3) & \text { C5-C12 } & 1.483(4) \\ \text { P2-C32 } & 1.846(3) & & \\ \text { P1-Mo-P2 } & 77.63(3) & \text { C1-C2-O1 } & 130.3(3) \\ \text { P1-Mo-C1 } & 87.27(8) & \text { C1-C2-O2 } & 109.0(3) \\ \text { P1-Mo-C4 } & 100.36(8) & \text { O1-C2-O2 } & 120.7(3) \\ \text { P1-Mo-C5 } & 134.73(8) & \text { C2-O2-C3 } & 115.3(3) \\ \text { P2-Mo-C1 } & 132.36(8) & \text { C1-C4-C5 } & 113.1(3) \\ \text { P2-Mo-C4 } & 101.46(7) & \text { C1-C4-C6 } & 117.7(3) \\ \text { P2-Mo-C5 } & 96.09(8) & \text { C5-C4-C6 } & 126.5(3) \\ \text { C2-C1-C4 } & 124.2(3) & \text { C4-C5-C12 } & 129.5(3)\end{array}$

than the other two Mo-C(allylic) bonds (Mo-C1 = 2.259(3) $\AA$, Mo-C4 = 2.328(3) $\AA$, and Mo-C5 = 2.324(3) $\AA$ ). The different configuration of the carbomethoxy group relative to the neighboring phenyl group (cis in $\mathbf{5}$ and trans in 6) could possibly be attributed to the additional hydrogen shift process in the formation of $\mathbf{6}$.

Treatment of $\mathbf{4}$ with $\mathrm{MeONa}$ in $\mathrm{MeOH}$ gave, in moderate yield, an unstable green complex, which decomposed at room temperature in $2 \mathrm{~h}$ in $\mathrm{CDCl}_{3}$. This solid product was isolated by precipitation from the $\mathrm{CH}_{2-}$ $\mathrm{Cl}_{2}$ solution of the product via addition of ether. The FAB mass spectrum of this complex displays peaks that could be attributed to the cyclopropenyl complex [Mo]$(\mathrm{CO}) \mathrm{C}=\mathrm{C}(\mathrm{Ph}) \mathrm{CHCN}(\mathbf{7})$. In the IR spectrum of $\mathbf{7}$, the absorption at $1846 \mathrm{~cm}^{-1}$ is assigned to the vibrational stretching of the terminal $\mathrm{CO}$ ligand, indicating that there is no nucleophilic addition. And in the ${ }^{31} \mathrm{P}$ NMR spectrum, chemical shifts of two singlet resonances at $\delta 105.4$ and 103.9 differ significantly from the range $(\delta$ 90.5 and 71.2 ) observed for $\mathbf{5}$ and $\mathbf{6}$. Unfortunately, we can obtain spectroscopic data only for this green compound, and there is no established data for a molybdenum cyclopropenyl complex for comparison. This is somewhat surprising since in the ruthenium system ${ }^{1}$ the presence of an electron-withdrawing $\mathrm{CN}$ substituent seemed to stabilize a number of cyclopropenyl complexes. In this Mo vinylidene system with a terminal $\mathrm{CO}$ ligand, the $\mathrm{CN}$ group provides no similar effect. In our attempts to carry out addition reactions of $\mathbf{4}$ using nucleophilic reagents other than $\mathrm{MeO}^{-}$, we do not observe any coupling products as in the reactions of $\mathbf{2}$ and 3.

In summary, we report high-yield preparation of three cationic molybednum vinylidene complexes $\{[\mathrm{Mo}](\mathrm{CO})=$ $\left.\mathrm{C}=\mathrm{C}(\mathrm{Ph}) \mathrm{CH}_{2} \mathrm{R}\right\} \mathrm{Br}\left(\mathbf{2}, \mathrm{R}=\mathrm{CH}=\mathrm{CH}_{2} ; \mathbf{3}, \mathrm{R}=\mathrm{C}_{6} \mathrm{H}_{5} ; \mathbf{4}, \mathrm{R}\right.$ $=\mathrm{CN})$. In the presence of $\mathrm{MeONa}$, the molybdenum vinylidene complexes $\mathbf{2}$ and $\mathbf{3}$, each containing a terminal carbonyl ligand, undergo nucleophilic addition at the $\mathrm{CO}$ ligand followed by a $\mathrm{C}-\mathrm{C}$ coupling reaction at $\mathrm{C} \alpha$ of the vinylidene ligand to give addition products. The site preference of this coupling reaction is possibly due to the relatively strong bond of $\mathrm{Ru}=\mathrm{C} \alpha$ and proximity

(11) (a) Staerker, K.; Curtis, M. D. Inorg. Chem. 1985, 24, 3006. (b) Lau, Y. Y. Huckabee, W. W.; Gipson, S. L. Inorg. Chim. Acta 1990 $172,41$. of the two groups on the ruthenium metal center. For the analogous CN-substituted vinylidene complex $\mathbf{4}$, the same reaction yielded an unstable cyclopropenyl complex through deprotonation.

\section{Experimental Section}

General Procedures. All manipulations were performed under nitrogen using vacuum-line, drybox, and standard Schlenk techniques. $\mathrm{CH}_{2} \mathrm{Cl}_{2}$ was distilled from $\mathrm{CaH}_{2}$ and diethyl ether and THF from $\mathrm{Na}$ /diphenylketyl. All other solvents and reagents were of reagent grade and were used as received. NMR spectra were recorded on Bruker AM-300WB and DMX-500 FT-NMR spectrometers at room temperature (unless states otherwise) and are reported in units of $\delta$ with residual protons in the solvents as a standard $\left(\mathrm{CDCl}_{3}, \delta 7.24\right.$ $\mathrm{C}_{2} \mathrm{D}_{6} \mathrm{O}, \delta$ 2.04). $\mathrm{FAB}$ mass spectra were recorded on a J $\mathrm{EOL}$ SX-102A spectrometer. Complex [Mo](CO)Cl $\left([\mathrm{Mo}]=\left(\eta^{5}\right.\right.$ $\left.\mathrm{C}_{5} \mathrm{H}_{5}\right)(\mathrm{dppe}) \mathrm{Mo}$, dppe $\left.=\mathrm{Ph}_{2} \mathrm{PCH}_{2} \mathrm{CH}_{2} \mathrm{PPh}_{2}\right)$ was prepared according to the methods reported in the literature. ${ }^{11}$ Elemental analyses and X-ray diffraction studies were carried out at the Regional Center of Analytical Instrumentation located at the National Taiwan University.

Preparation of [Mo](CO)C $\equiv \mathbf{C P h}$ (1). To a sample of [Mo]$(\mathrm{CO}) \mathrm{Cl}(0.22 \mathrm{~g}, 0.35 \mathrm{mmol})$ dissolved in $30 \mathrm{~mL}$ of THF at room temperature was added a THF solution of lithium phenylacetylide $(1.0 \mathrm{M}, 0.40 \mathrm{~mL})$ via a syringe. The resulting mixture was heated under reflux for $1 \mathrm{~h}$. After removal of all volatile substances in vacuo, $20 \mathrm{~mL}$ of $\mathrm{Et}_{2} \mathrm{O}$ was added to the residue under nitrogen, and the extract was filtered. The solvent of the filtrate was removed under vacuum to afford the yellow product 1, which was further recrystallized from a 1:1 mixture of hexane/ $\mathrm{CH}_{2} \mathrm{Cl}_{2}$ to afford crystals of $\mathbf{1}(0.14 \mathrm{~g}, 61 \%$ yield). Spectroscopic data for 1: IR $\left(\mathrm{cm}^{-1}, \mathrm{CH}_{2} \mathrm{Cl}_{2}\right) 2074\left(\mathrm{~s}, v_{\mathrm{C}} \equiv \mathrm{C}\right), 1850$ $\left(\mathrm{s}, v_{\mathrm{CO}}\right) ;{ }^{1} \mathrm{H} \mathrm{NMR}\left(\mathrm{CDCl}_{3}\right) \delta 7.95-6.64(\mathrm{~m}, 25 \mathrm{H}, \mathrm{Ph}), 4.49(\mathrm{~d}$, $\left.\mathrm{J}_{\mathrm{H}-\mathrm{P}}=1.6 \mathrm{~Hz}, 5 \mathrm{H}, \mathrm{Cp}\right), 2.40,1.78\left(\mathrm{~m}, 4 \mathrm{H}, \mathrm{CH}_{2} \mathrm{CH}_{2}\right) ;{ }^{13} \mathrm{C} \mathrm{NMR}$ $\left(\mathrm{CDCl}_{3}\right) \delta 245.0\left(\mathrm{~d}, \mathrm{~J}_{\mathrm{C}-\mathrm{P}}=22.2 \mathrm{~Hz}, \mathrm{CO}\right), 141.9-119.2(\mathrm{Ph})$, $91.0(\mathrm{Cp}), 31.8\left(\mathrm{dd}, \mathrm{J}_{\mathrm{c}-\mathrm{p}}=28.0 \mathrm{~Hz}\right.$, J $\mathrm{c}-\mathrm{P}=18.6 \mathrm{~Hz}, \mathrm{PCH}_{2}$ ), $28.6\left(\mathrm{dd}, \mathrm{J}_{\mathrm{c}-\mathrm{p}}=22.0 \mathrm{~Hz}\right.$, J $\left.\mathrm{c}-\mathrm{p}=17.3 \mathrm{~Hz}, \mathrm{PCH}_{2}\right) ;{ }^{31} \mathrm{P} \mathrm{NMR}$ $\left(\mathrm{CDCl}_{3}\right) \delta 90.4\left(\mathrm{~d}, \mathrm{~J}_{\mathrm{p}-\mathrm{p}}=37.2 \mathrm{~Hz}\right), 78.7\left(\mathrm{~d}, \mathrm{~J}_{\mathrm{p}-\mathrm{p}}=37.2 \mathrm{~Hz}\right)$; MS (FAB, m/z, Mo98) $690\left(\mathrm{M}^{+}\right), 662\left(\mathrm{M}^{+}-\mathrm{CO}\right)$. Anal. Calcd for $\mathrm{C}_{40} \mathrm{H}_{34} \mathrm{OP}_{2} \mathrm{Mo}$ : $\mathrm{C}, 69.77 ; \mathrm{H}, 4.98$. Found: $\mathrm{C}, 70.02 ; \mathrm{H}, 4.79$.

Reaction of [Mo](CO)CI with $\mathbf{H C} \equiv \mathbf{C P h}$. To a sample of $[\mathrm{Mo}](\mathrm{CO}) \mathrm{Cl}(0.20 \mathrm{~g}, 0.32 \mathrm{mmol})$ dissolved in $50 \mathrm{~mL}$ of $\mathrm{MeOH}$ at room temperature was added phenylacetylene $(0.21 \mathrm{~mL}$, $1.82 \mathrm{mmol}$ ) via a syringe. The resulting mixture was heated under reflux for $2.5 \mathrm{~h}$ to give a green solution. After removal of all volatile substances in vacuo, $20 \mathrm{~mL}$ of $\mathrm{CH}_{2} \mathrm{Cl}_{2}$ was added to the residue, and the extract was filtered. The sol vent of the filtrate was reduced under vacuum to about $5 \mathrm{~mL}$ and the solution added to a stirred solution of $\mathrm{Et}_{2} \mathrm{O}$ to give green precipitates. The solid was collected by filtration and washed with $\mathrm{Et}_{2} \mathrm{O}$ to give the green product $\left\{[\mathrm{Mo}]\left(\eta^{2}-\mathrm{HC} \equiv \mathrm{CPh}\right\} \mathrm{Cl}(0.20\right.$ g, 90\% yield). Spectroscopic data: ${ }^{1} \mathrm{H}$ NMR $\left(\mathrm{CDCl}_{3}\right) \delta 10.02$ $\left(\mathrm{t}, \mathrm{J}_{\mathrm{H}-\mathrm{P}}=13.8 \mathrm{~Hz}, \mathrm{CH}\right) ; 7.50-6.82(\mathrm{~m}, 25 \mathrm{H}, \mathrm{Ph}), 5.03(\mathrm{~s}, 5 \mathrm{H}$, $\mathrm{Cp}), 2.70\left(\mathrm{~m}, 4 \mathrm{H}, \mathrm{PCH}_{2} \mathrm{CH}_{2} \mathrm{P}\right)$; ${ }^{31} \mathrm{P} \mathrm{NMR}\left(\mathrm{CDCl}_{3}\right) \delta 79.3(\mathrm{~s})$; MS (FAB, m/z, Mo $\left.{ }^{98}\right) 663\left(\mathrm{M}^{+}\right)$. Anal. Calcd for $\mathrm{C}_{39} \mathrm{H}_{35} \mathrm{P}_{2} \mathrm{MoCl}$ : C, 67.20; H, 5.06. Found: C, 67.21; H, 5.23.

Reaction of [Mo](CO)Cl with $\mathrm{HC} \equiv \mathrm{CPh}$ in the Presence of CO. To a sample of [Mo] $(\mathrm{CO}) \mathrm{Cl}(0.10 \mathrm{~g}, 0.16 \mathrm{mmol})$ dissolved in $30 \mathrm{~mL}$ of $\mathrm{MeOH}$ at room temperature was added phenylacetylene $(0.11 \mathrm{~mL}, 0.92 \mathrm{mmol})$ via a syringe. The resulting mixture was heated under reflux for $2.5 \mathrm{~h}$ to give a green solution. After cooling to room temperature the solution was treated with $1 \mathrm{~atm}$ of $\mathrm{CO}$ gas and the solution turned yellow. After removal of all volatile substances in vacuo, $20 \mathrm{~mL}$ of $\mathrm{CH}_{2-}$ $\mathrm{Cl}_{2}$ was added to the residue, and the extract was filtered. The solvent of the filtrate was reduced under vacuum to about 5 $\mathrm{mL}$ and the solution added to a stirred solution of hexane to give yellow precipitates, which were collected by filtration and washed with hexane to afford $\{[\mathrm{Mo}](\mathrm{CO})(=\mathrm{C}=\mathrm{CHPh}\} \mathrm{Cl},(0.12$ 
g, 87\% yield). Spectroscopic data: IR ( $\left.\mathrm{cm}^{-1}, \mathrm{CH}_{2} \mathrm{Cl}_{2}\right) 1909$ (s, $\left.v_{\mathrm{CO}}\right) ;{ }^{1} \mathrm{H} \mathrm{NMR}\left(\mathrm{CDCl}_{3}\right) \delta 7.50-6.82(\mathrm{~m}, 25 \mathrm{H}, \mathrm{Ph}), 5.05(\mathrm{~s}, 5 \mathrm{H}$, Cp), $4.78(\mathrm{~s}, 1 \mathrm{H},=\mathrm{CH}), 2.70\left(\mathrm{~m}, 4 \mathrm{H}, \mathrm{PCH}_{2} \mathrm{CH}_{2} \mathrm{P}\right)$; ${ }^{31} \mathrm{P} \mathrm{NMR}$ $\left(\mathrm{CDCl}_{3}\right) \delta 58.5(\mathrm{~d}, \mathrm{~J} \mathrm{p}-\mathrm{p}=18.0 \mathrm{~Hz}), 15.5(\mathrm{~d}, \mathrm{~J}-\mathrm{p}=18.0 \mathrm{~Hz})$; MS (FAB, m/z, M o98) $691\left(\mathrm{M}^{+}\right), 663\left(\mathrm{M}^{+}-\mathrm{CO}\right)$. Anal. Calcd for $\mathrm{C}_{40} \mathrm{H}_{35} \mathrm{OP}_{2} \mathrm{MoCl}$ : C, 66.26; $\mathrm{H}, 4.87$. Found: $\mathrm{C}, 66.41 ; \mathrm{H}$, 4.98. This reaction is reversible. If the $\mathrm{MeOH}$ solution of the product was heated under refluxing, decarbonylation occurred and the $\eta^{2}$-acetylide complex was obtained in quantitative yield. The carbonylation reaction in the presence of $\mathrm{MeONa}$ (54 mg, $0.10 \mathrm{mmol}$ in $30 \mathrm{~mL}$ of $\mathrm{MeOH}$ ) gave the acetylide complex $\mathbf{1}$ in $92 \%$ yield.

Reaction of 1 with Allyl Bromide. To a sample of $\mathbf{1}$ (0.60 g, $0.87 \mathrm{mmol}$ ) dissolved in $50 \mathrm{~mL}$ of $\mathrm{CHCl}_{3}$ at room temperature was added excess $\mathrm{BrCH}_{2} \mathrm{CH}=\mathrm{CH}_{2}(0.10 \mathrm{~mL}, 1.16 \mathrm{mmol})$ via a syringe. The resulting mixture was stirred for $36 \mathrm{~h}$ in the dark. The color of the reaction mixture changed from yellow to brown within this period. After removal of all volatile substances in vacuo, $10 \mathrm{~mL}$ of $\mathrm{CH}_{2} \mathrm{Cl}_{2}$ was added to the residue under nitrogen, and the extract was filtered. The solvent of the filtrate was removed under vacuum to afford a brown residue. The residue was redissolved in $5 \mathrm{~mL}$ of $\mathrm{CH}_{2} \mathrm{Cl}_{2}$ and was then added dropwise to a stirred $\mathrm{Et}_{2} \mathrm{O}$ solution to cause precipitation of brown solid, which was collected by filtration and washed with $\mathrm{Et}_{2} \mathrm{O}$ under nitrogen and dried under vacuum to afford $\left[[\mathrm{Mo}](\mathrm{CO})=\mathrm{C}=\mathrm{C}(\mathrm{Ph}) \mathrm{CH}_{2} \mathrm{CH}=\mathrm{CH}_{2}\right] \mathrm{Br}$ (2) $(0.57 \mathrm{~g}, 81 \%$ yield). Spectroscopic data for 2: IR ( $\left.\mathrm{cm}^{-1}, \mathrm{CH}_{2} \mathrm{Cl}_{2}\right) 1931$ (s, $\left.v_{\mathrm{CO}}\right)$; ${ }^{1} \mathrm{H} \mathrm{NMR}\left(\mathrm{CDCl}_{3}\right) \delta 7.72-6.82(\mathrm{~m}, 25 \mathrm{H}, \mathrm{Ph}), 5.62(\mathrm{~m}, \mathrm{~J} \mathrm{H}-\mathrm{H}=$ 17.1, 10.1, 6.3, $6.0 \mathrm{~Hz}, 1 \mathrm{H},=\mathrm{CH}) ; 5.20$ (s, 5H, Cp), $5.00(\mathrm{~m}$, $\mathrm{J} \mathrm{H}-\mathrm{H}=17.1,1.5 \mathrm{~Hz}, 1 \mathrm{H},=\mathrm{CH}), 4.96(\mathrm{~m}, \mathrm{~J} \mathrm{H}-\mathrm{H}=10.1,1.5 \mathrm{~Hz}$, $1 \mathrm{H},=\mathrm{CH}), 3.44,3.22\left(\mathrm{~m}, 2 \mathrm{H}, \mathrm{PCH}_{2}\right), 2.87$ (ddd, J $\mathrm{H}-\mathrm{H}=15.6$, $6.3 \mathrm{~Hz}, \mathrm{~J}_{\mathrm{H}-\mathrm{P}}=2.0 \mathrm{~Hz}, 1 \mathrm{H}$ of $\left.\mathrm{CH}_{2}\right), 2.78\left(\mathrm{ddd}, \mathrm{J}_{\mathrm{H}-\mathrm{H}}=15.6,6.0\right.$ $\mathrm{Hz}, \mathrm{J}_{\mathrm{P}-\mathrm{H}}=2.8 \mathrm{~Hz}, 1 \mathrm{H}$ of $\left.\mathrm{CH}_{2}\right), 2.42\left(\mathrm{~m}, 2 \mathrm{H}, \mathrm{PCH}_{2}\right) ;{ }^{13} \mathrm{C} \mathrm{NMR}$ $\left(\mathrm{CDCl}_{3}\right) \delta 358.4\left(\mathrm{dd}, \mathrm{J}_{\mathrm{c}-\mathrm{P}}=36.0,6.5 \mathrm{~Hz}, \mathrm{C} \alpha\right), 227.4$ (d, J c-p $=$ $21.8 \mathrm{~Hz}, \mathrm{CO}), 135.0(\mathrm{CH}), 134.3-126.5(\mathrm{Ph}), 116.8\left(=\mathrm{CH}_{2}\right), 95.7$ (Cp), $33.9\left(\mathrm{CH}_{2}\right), 30.1$ (dd, J c-p $\left.=27.1,13.1 \mathrm{~Hz}, \mathrm{PCH}_{2}\right), 28.9$ $\left(\mathrm{dd}, \mathrm{J}_{\mathrm{C}-\mathrm{P}}=28.5,12.3 \mathrm{~Hz}, \mathrm{PCH}_{2}\right) ;{ }^{31} \mathrm{P} \mathrm{NMR}\left(\mathrm{CDCl}_{3}\right) \delta 71.5(\mathrm{~d}$, J $p-p=37.5 \mathrm{~Hz}), 67.0(\mathrm{~d}$, J $\mathrm{p}-\mathrm{p}=37.5 \mathrm{~Hz})$; $\mathrm{MS}\left(\mathrm{FAB}, \mathrm{m} / \mathrm{z}, \mathrm{Mo}^{98}\right)$ $731\left(\mathrm{M}^{+}\right), 703\left(\mathrm{M}^{+}-\mathrm{CO}\right)$. A nal. Calcd for $\mathrm{C}_{43} \mathrm{H}_{39} \mathrm{OP}_{2} \mathrm{MoBr}: \mathrm{C}$, 63.79; H, 4.86. Found: C, 64.01; H, 4.97.

Reaction of 1 with Benzyl Bromide. A mixture of $\mathbf{1}(0.30$ g, $0.43 \mathrm{mmol})$ and $\mathrm{BrCH}_{2} \mathrm{C}_{6} \mathrm{H}_{5}(0.11 \mathrm{~mL}, 0.84 \mathrm{mmol})$ was dissolved in $40 \mathrm{~mL}$ of $\mathrm{CHCl}_{3}$ at room temperature, and the resulting mixture was stirred for $36 \mathrm{~h}$ in the dark. The color of the reaction mixture changed from yellow to red. After removal of the solvent in vacuo, $10 \mathrm{~mL}$ of $\mathrm{CH}_{2} \mathrm{Cl}_{2}$ was added to the residue under nitrogen, and the extract was filtered. The solvent of the filtrate was reduced in volume to ca. $5 \mathrm{~mL}$. The sol ution was added dropwise to a stirred $\mathrm{Et}_{2} \mathrm{O}$ solution to give a brown precipitate. The solid was collected by filtration and washed with $5 \mathrm{~mL}$ of $\mathrm{Et}_{2} \mathrm{O}$ under nitrogen. The solid was dried under vacuum to afford the brown product [[Mo] $(\mathrm{CO})=$ $\left.\mathrm{C}=\mathrm{C}(\mathrm{Ph}) \mathrm{CH}_{2} \mathrm{Ph}\right] \mathrm{Br}$ (3) $(0.27 \mathrm{~g}, 73 \%$ yield). Spectroscopic data for 3: IR $\left(\mathrm{cm}^{-1}, \mathrm{CH}_{2} \mathrm{Cl}_{2}\right) 1931$ (s, $\left.v_{\mathrm{CO}}\right) ;{ }^{1} \mathrm{H} \mathrm{NMR}\left(\mathrm{CDCl}_{3}\right) \delta 7.98-$ $6.73(\mathrm{~m}, 30 \mathrm{H}, \mathrm{Ph}), 5.09$ (s, 5H, Cp), 3.42 (dd, J $\mathrm{H}-\mathrm{H}=14.5 \mathrm{~Hz}$, $\mathrm{J}_{\mathrm{H}-\mathrm{P}}=2.0 \mathrm{~Hz}, 1 \mathrm{H}$ on $\left.\mathrm{CH}_{2} \mathrm{Ph}\right), 3.27\left(\mathrm{dd}, \mathrm{J}_{\mathrm{H}-\mathrm{H}}=14.5 \mathrm{~Hz}, \mathrm{~J}_{\mathrm{H}-\mathrm{P}}\right.$ $=3.7 \mathrm{~Hz}, 1 \mathrm{H}$ on $\left.\mathrm{CH}_{2} \mathrm{Ph}\right), 3.20\left(\mathrm{~m}, 2 \mathrm{H}, \mathrm{CH}_{2}\right), 2.38\left(\mathrm{~m}, 2 \mathrm{H}, \mathrm{CH}_{2}\right)$; ${ }^{13} \mathrm{C} \mathrm{NMR}\left(\mathrm{CDCl}_{3}\right) \delta 356.7\left(\mathrm{dd}, \mathrm{J}_{\mathrm{C}-\mathrm{P}}=37.8 \mathrm{~Hz}, 5.6 \mathrm{~Hz}, \mathrm{C} \alpha\right)$, $227.8\left(\mathrm{~d}, J_{\mathrm{c}-\mathrm{p}}=20.6 \mathrm{~Hz}, \mathrm{CO}\right), 134.1-126.8(\mathrm{Ph}), 95.9(\mathrm{Cp})$, $36.0\left(\mathrm{CH}_{2} \mathrm{Ph}\right), 30.3$ (dd, J $\left.\mathrm{C}-\mathrm{P}=28.3,13.6 \mathrm{~Hz}, \mathrm{PCH}_{2}\right), 28.5$ (dd,

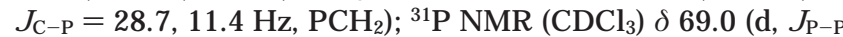
$=36.3 \mathrm{~Hz}), 66.2(\mathrm{~d}, \mathrm{~J}$ P-P $=36.3 \mathrm{~Hz}) ; \mathrm{MS}\left(\mathrm{FAB}, \mathrm{m} / \mathrm{z}, \mathrm{Mo}^{98}\right) 781$ $\left(\mathrm{M}^{+}\right), 753\left(\mathrm{M}^{+}-\mathrm{CO}\right)$. Anal. Calcd for $\mathrm{C}_{47} \mathrm{H}_{41} \mathrm{OP}_{2} \mathrm{MoBr}$ : C, 65.67; H, 4.81. Found: C, 65.60; H, 4.99.

Reaction of $\mathbf{1}$ with Bromoacetonitrile. To a sample of $\mathbf{1}$ $(0.61 \mathrm{~g}, 0.87 \mathrm{mmol})$ dissolved in $40 \mathrm{~mL}$ of $\mathrm{CHCl}_{3}$ at room temperature was added excess $\mathrm{BrCH}_{2} \mathrm{CN}(0.1 \mathrm{~mL}, 1.44 \mathrm{mmol})$ via a syringe. The resulting mixture was stirred for $24 \mathrm{~h}$ in the dark. The color of the reaction mixture changed from yellow to brown within $12 \mathrm{~h}$. After removal of all volatile substances in vacuo, $10 \mathrm{~mL}$ of $\mathrm{CH}_{2} \mathrm{Cl}_{2}$ was added to the residue under nitrogen, and the extract was filtered. The solvent of the filtrate was reduced in volume under vacuum to ca. $5 \mathrm{~mL}$. The solution was added dropwise to a stirred $\mathrm{Et}_{2} \mathrm{O}$ solution to give brown precipitate. The solid was collected by filtration and washed with $\mathrm{Et}_{2} \mathrm{O}$ under nitrogen. The solid was dried under vacuum to afford $\left[[\mathrm{Mo}](\mathrm{CO})=\mathrm{C}=\mathrm{C}(\mathrm{Ph}) \mathrm{CH}_{2} \mathrm{CN}\right] \mathrm{Br}$ (4) (0.52 g, 74\% yield). Spectroscopic data for 4: IR $\left(\mathrm{cm}^{-1}, \mathrm{CH}_{2^{-}}\right.$ $\left.\mathrm{Cl}_{2}\right) 1977\left(\mathrm{~s}, v_{\mathrm{CO}}\right) ;{ }^{1} \mathrm{H} \mathrm{NMR}\left(\mathrm{CDCl}_{3}\right) \delta 7.74-6.77(\mathrm{~m}, 25 \mathrm{H}, \mathrm{Ph})$, 5.21 (s, 5H, Cp), 3.58, 3.29, 2.52, $2.33\left(\mathrm{~m}, 4 \mathrm{H}, \mathrm{PCH}_{2} \mathrm{CH}_{2} \mathrm{P}\right)$, $2.95\left(\mathrm{~m}, \mathrm{~J} \mathrm{H}-\mathrm{H}=18.2 \mathrm{~Hz}, \mathrm{~J} H-\mathrm{P}=5.2 \mathrm{~Hz}, 1 \mathrm{H}\right.$ of $\left.\mathrm{CH}_{2} \mathrm{CN}\right), 2.84$ $\left(\mathrm{m}, \mathrm{J}_{\mathrm{H}-\mathrm{H}}=18.2 \mathrm{~Hz}, \mathrm{~J}_{\mathrm{H}-\mathrm{P}}=5.5 \mathrm{~Hz}, 1 \mathrm{H}\right.$ of $\left.\mathrm{CH}_{2} \mathrm{CN}\right) ;{ }^{31} \mathrm{P} \mathrm{NMR}$ $\left(\mathrm{CDCl}_{3}\right) \delta 66.8,63.7(2 \mathrm{~d}, \mathrm{~J}$ p-p $=30.7 \mathrm{~Hz})$; MS (FAB, m/z) 730 $\left(\mathrm{M}^{+}\right), 702\left(\mathrm{M}^{+}-\mathrm{CO}\right)$. Anal. Calcd for $\mathrm{C}_{42} \mathrm{H}_{36} \mathrm{NOBrP}_{2} \mathrm{Mo}$ (808.5): C, 62.39; H, 4.49; N, 1.73. Found: C, 62.17; H, 4.68; N, 1.76.

Reaction of $\mathbf{2}$ with NaOMe in Methanol. To a sample of $2(0.33 \mathrm{~g}, 0.41 \mathrm{mmol})$ dissolved in $10 \mathrm{~mL}$ of methanol at room temperature was added a methanol solution of sodium methoxide $(0.15 \mathrm{~g}, 2.78 \mathrm{mmol})$ via a cannula. An orange powder precipitated after $1 \mathrm{~h}$, and the resulting solution was stirred for $4 \mathrm{~h}$ as the color of the reaction mixture changed from red to yellow. The product was collected by filtration and washed with $20 \mathrm{~mL}$ of methanol under nitrogen. The powder was dried under vacuum to afford the product $[\mathrm{Mo}]\left[\eta^{3}-\mathrm{C}\left(\mathrm{CO}_{2} \mathrm{Me}\right)=\mathrm{C}(\mathrm{Ph})\right.$ $\mathrm{CH}_{2} \mathrm{CH}=\mathrm{CH}_{2}$ ] (5) $(0.25 \mathrm{~g}, 80 \%$ yiel d). The powder was further recrystallized from a mixture of hexane/ $\mathrm{CH}_{2} \mathrm{Cl}_{2}$ to afford yellow crystals of $\mathbf{5}$ for $\mathrm{X}$-ray diffraction analysis. Spectroscopic data for 5: IR $\left(\mathrm{cm}^{-1}, \mathrm{CH}_{2} \mathrm{Cl}_{2}\right) 1673\left(\mathrm{~s}, v_{\mathrm{CO}}\right)$; ${ }^{1} \mathrm{H} \mathrm{NMR}\left(\mathrm{C}_{6} \mathrm{D}_{6}\right) \delta 8.25-$ $6.71(\mathrm{~m}, 25 \mathrm{H}, \mathrm{Ph}), 4.71(\mathrm{~s}, 5 \mathrm{H}, \mathrm{Cp}), 3.66\left(\mathrm{~d}, \mathrm{~J} \mathrm{H}_{-\mathrm{H}}=17.2 \mathrm{~Hz}\right.$, $\left.1 \mathrm{H},=\mathrm{CH}_{2}\right), 3.41\left(\mathrm{~s}, 3 \mathrm{H}, \mathrm{OCH}_{3}\right), 2.82\left(\mathrm{br}, 1 \mathrm{H}, \mathrm{PCH}_{2}\right), 2.58(\mathrm{br}$, $\left.1 \mathrm{H},=\mathrm{CH}_{2}\right), 2.52\left(\mathrm{br}, 1 \mathrm{H}, \mathrm{PCH}_{2}\right), 2.35\left(\mathrm{br}, 1 \mathrm{H}, \mathrm{PCH}_{2}\right), 2.02(\mathrm{br}$, $\left.1 \mathrm{H}, \mathrm{PCH}_{2}\right), 1.97\left(\mathrm{br}, 1 \mathrm{H}, \mathrm{CH}_{2}\right), 1.78(\mathrm{br}, 1 \mathrm{H},=\mathrm{CH}), 1.70(\mathrm{br}$, $\left.1 \mathrm{H}, \mathrm{CH}_{2}\right) ;{ }^{13} \mathrm{C} \mathrm{NMR}\left(\mathrm{C}_{6} \mathrm{D}_{6}\right) \delta 180.6\left(\mathrm{CO}_{2}\right), 144.4-124.7(\mathrm{Ph})$, $87.6(\mathrm{Cp}), 60.3\left(\mathrm{dd}, \mathrm{J}_{\mathrm{c}-\mathrm{p}}=5.4,4.0 \mathrm{~Hz},=\mathrm{CH}\right), 49.4\left(\mathrm{OCH}_{3}\right)$, $47.6\left(\mathrm{~d}, \mathrm{~J}_{\mathrm{c}-\mathrm{p}}=5.9 \mathrm{~Hz},=\mathrm{CH}_{2}\right), 34.6\left(\mathrm{CH}_{2}\right), 29.1$ (dd, J c-p $=$ $29.9 \mathrm{~Hz}$, J $\left.c_{-p}=15.0 \mathrm{~Hz}, \mathrm{PCH}_{2}\right), 27.9\left(\mathrm{dd}, \mathrm{J}_{\mathrm{c}-\mathrm{p}}=25.8,14.4\right.$ $\mathrm{Hz}, \mathrm{PCH}_{2}$ ); ${ }^{31 \mathrm{P} N M R}\left(\mathrm{C}_{6} \mathrm{D}_{6}\right) \delta 90.5$ (s), $71.2(\mathrm{~s}) ; \mathrm{MS}(\mathrm{FAB}, \mathrm{m} / \mathrm{z}$, $\left.\mathrm{Mo}^{98}\right) 762\left(\mathrm{M}^{+}\right)$. Anal. Calcd for $\mathrm{C}_{44} \mathrm{H}_{42} \mathrm{O}_{2} \mathrm{P}_{2} \mathrm{Mo}$ o: C, 69.47; $\mathrm{H}$, 5.57. Found: C, 69.32; $\mathrm{H}, 5.79$.

Reaction of $\mathbf{3}$ with NaOMe in Methanol. A mixture of $\mathbf{3}$ $(0.40 \mathrm{~g}, 0.46 \mathrm{mmol})$ and sodium methoxide $(0.20 \mathrm{~g}, 3.70 \mathrm{mmol})$ was dissolved in $30 \mathrm{~mL}$ of methanol at room temperature. The solution was stirred for $1 \mathrm{~h}$, and a red product precipitated. The product was collected by filtration, washed with methanol under nitrogen, and dried under vacuum to afford the red compound $[\mathrm{Mo}]\left(\eta^{3}-\mathrm{CH}\left(\mathrm{CO}_{2} \mathrm{CH}_{3}\right) \mathrm{C}(\mathrm{Ph}) \mathrm{CHPh}\right)(6)(0.31 \mathrm{~g}, 83 \%$ yield). The solid was further recrystallized from a mixture of $\mathrm{Et}_{2} \mathrm{O} / \mathrm{CH}_{2} \mathrm{Cl}_{2}$ to afford red crystals for diffraction analysis. Spectroscopic data for 6: IR $\left(\mathrm{cm}^{-1}, \mathrm{CH}_{2} \mathrm{Cl}_{2}\right) 1674\left(\mathrm{~s}, v_{\mathrm{CO}}\right) ;{ }^{1} \mathrm{H}$ $\operatorname{NMR}\left(\mathrm{CD}_{2} \mathrm{Cl}_{2}\right) \delta 7.98-6.14(\mathrm{~m}, 30 \mathrm{H}, \mathrm{Ph}), 4.62(\mathrm{~s}, 1 \mathrm{H}$, syn $\mathrm{H})$, $3.88(\mathrm{~d}$, J H-P $=11.4 \mathrm{~Hz}, 1 \mathrm{H}$, anti H), $3.73(\mathrm{~s}, 5 \mathrm{H}, \mathrm{Cp}), 3.71$ (s, $\left.3 \mathrm{H}, \mathrm{OCH}_{3}\right), 2.68\left(\mathrm{~m}, 1 \mathrm{H}, \mathrm{PCH}_{2}\right), 2.53\left(\mathrm{~m}, 1 \mathrm{H}, \mathrm{PCH}_{2}\right), 2.47(\mathrm{~m}$, $\left.1 \mathrm{H}, \mathrm{PCH}_{2}\right), 1.90\left(\mathrm{~m}, 1 \mathrm{H}, \mathrm{PCH}_{2}\right) ;{ }^{13} \mathrm{C} \mathrm{NMR}\left(\mathrm{CD}_{2} \mathrm{Cl}_{2}\right) \delta 183.2(\mathrm{~d}$, $\mathrm{J}_{\mathrm{c}-\mathrm{P}}=3.5 \mathrm{~Hz}, \mathrm{CO}_{2}$ ), 149.0-125.0 (Ph), $92.4(\mathrm{Cp}), 90.3$ (t, J c-P $=3.1 \mathrm{~Hz}, \mathrm{C}(\mathrm{Ph})), 50.2\left(\mathrm{OCH}_{3}\right), 49.2\left(\mathrm{~d}, \mathrm{~J}_{\mathrm{c}-\mathrm{P}}=2.7 \mathrm{~Hz}, \mathrm{CHPh}\right)$, $48.7\left(\mathrm{~d}, \mathrm{~J}_{\mathrm{c}-\mathrm{P}}=4.5 \mathrm{~Hz}, \mathrm{CHCO}_{2} \mathrm{CH}_{3}\right), 33.7\left(\mathrm{dd}, \mathrm{J} \mathrm{c}_{-\mathrm{P}}=28.1,14.3\right.$ $\mathrm{Hz}, \mathrm{PCH}_{2}$ ), $24.2\left(\mathrm{dd}, \mathrm{J}_{\mathrm{c}-\mathrm{P}}=23.1,12.9 \mathrm{~Hz}, \mathrm{PCH}_{2}\right.$ ); ${ }^{31} \mathrm{P} \mathrm{NMR}$ $\left(\mathrm{CD}_{2} \mathrm{Cl}_{2}\right) \delta 71.3(\mathrm{~d}, \mathrm{~J} \mathrm{p}-\mathrm{p}=36.8 \mathrm{~Hz}), 72.2(\mathrm{~d}, \mathrm{~J} \mathrm{p}-\mathrm{p}=36.8 \mathrm{~Hz})$; MS (FAB, m/z, Mo $\left.{ }^{98}\right) 812\left(\mathrm{M}^{+}\right)$. Anal. Calcd for $\mathrm{C}_{48} \mathrm{H}_{44} \mathrm{O}_{2} \mathrm{P}_{2^{-}}$ Mo: C, 71.11; H, 5.47. Found: C, 71.06; H, 5.59.

Deprotonation of $\left[\mathrm{Cp}\right.$ (dppe)(CO)Mo $\left.=\mathrm{C}=\mathrm{C}(\mathrm{Ph}) \mathrm{CH}_{2} \mathrm{CN}\right]-$ Br by NaOMe. To a sample of $\mathbf{4}(0.11 \mathrm{~g}, 0.14 \mathrm{mmol})$ dissolved in $15 \mathrm{~mL}$ of $\mathrm{MeOH}$ at room temperature was added $5 \mathrm{~mL}$ of a $\mathrm{MeOH}$ solution of sodium methoxide $(0.05 \mathrm{~g}, 1.9 \mathrm{mmol})$ via cannula. The color of the solution changed from red to green immediately. After removal of the solvent in vacuo, $2 \mathrm{~mL}$ of $\mathrm{CH}_{2} \mathrm{Cl}_{2}$ and $20 \mathrm{~mL}$ of hexane were added to the residue under nitrogen, and the extract was filtered. The solvent of the filtrate was removed under vacuum to afford a green residue. The residue was redissolved in $2 \mathrm{~mL}$ of $\mathrm{CH}_{2} \mathrm{Cl}_{2}$. The solution was added dropwise to a stirred $\mathrm{Et}_{2} \mathrm{O}$ solution to give green 
Table 3. Crystal and Intensity Collection Data for $\mathrm{Cp}$ (dppe) MoC $(\mathrm{COOMe})=\mathrm{C}(\mathrm{Ph}) \mathrm{CH}_{2} \mathrm{C}=\mathrm{CH}_{2}$ (5) and Cp(dppe)MoCH(COOMe)C(Ph)CHPh (6)

\begin{tabular}{|c|c|c|}
\hline & 5 & 6 \\
\hline mol formula & $\mathrm{C}_{45} \mathrm{H}_{44} \mathrm{O}_{2} \mathrm{P}_{2} \mathrm{Cl}_{2} \mathrm{Mo}$ & $\mathrm{C}_{48} \mathrm{H}_{44} \mathrm{O}_{2} \mathrm{P}_{2} \mathrm{Mo}$ \\
\hline mol wt & 845.63 & 810.71 \\
\hline space group & $\mathrm{P} 2{ }_{1} / \mathrm{C}$ & $P \overline{1}$ \\
\hline $\mathrm{a}, \AA$ & 17.998(5) & $9.6178(1)$ \\
\hline $\mathrm{b}, \AA$ & $8.647(3)$ & $10.8305(2)$ \\
\hline$c, \AA$ & $26.080(5)$ & $21.3254(3)$ \\
\hline$\alpha$, deg & & $96.911(1)$ \\
\hline$\beta$, deg & $100.30(2)$ & $94.388(1)$ \\
\hline$\gamma$, deg & & 113.258(1) \\
\hline $\mathrm{V}, \AA^{3}$ & 3993.6(19) & $2007.22(5)$ \\
\hline Z & 4 & 2 \\
\hline $\begin{array}{l}\text { cryst dimens, } \mathrm{mm}^{3} \\
\text { MoK } \alpha \text { radiation: } \gamma, \AA\end{array}$ & $0.30 \times 0.35 \times 0.40$ & $\begin{array}{l}0.20 \times 0.25 \times 0.35 \\
0.71073\end{array}$ \\
\hline $\begin{array}{l}\theta \text { range for data } \\
\text { collection }\end{array}$ & $0.55-25.0$ & $0.97-25.0$ \\
\hline limiting indices (h, k, I) & $\begin{array}{l}-21,21 ; 0,10 \\
0,30\end{array}$ & $\begin{array}{l}-12,12 ;-14,14 ; \\
-28,28\end{array}$ \\
\hline no. of reflns collected & 7015 & 16793 \\
\hline no. of ind reflns & 4949 & 7071 \\
\hline max. and min. transmn & 0.868 and 0.819 & $0.492 / 0.408$ \\
\hline refinement method & full-matrix leas & t-squares on $\mathrm{F}^{2}$ \\
\hline $\begin{array}{l}\text { no. of data/restraints/ } \\
\text { params }\end{array}$ & $4949 / 0 / 470$ & 7071/0/479 \\
\hline $\begin{array}{l}\text { GOF } \\
\text { final } R \text { indices }\end{array}$ & 1.55 & 1.196 \\
\hline$[\mathrm{I}>2 \sigma(\mathrm{I})]$ & $0.034 / 0.037$ & $0.0411 / 0.1386$ \\
\hline all data & & $0.0451 / 0.1434$ \\
\hline$\Delta \rho$ (in final map), e/Å & $-0.470,+0.490$ & $-0.846,+0.507$ \\
\hline
\end{tabular}

precipitates. The solid was collected by filtration, washed with $\mathrm{Et}_{2} \mathrm{O}$ under nitrogen, and dried under vacuum to afford a green solid, $\mathrm{Cp}$ (dppe)(CO)Mo- $\mathrm{C}=\mathrm{C}(\mathrm{Ph}) \mathrm{CHCN}$ (7) $(0.052 \mathrm{~g}, 53 \%$ yield). Spectroscopic data for 7: IR ( $\left.\mathrm{cm}^{-1}, \mathrm{CH}_{2} \mathrm{Cl}_{2}\right) 1846\left(\mathrm{~s}, v_{\mathrm{CO}}\right)$; ${ }^{1} \mathrm{H}$ NMR $\left(\mathrm{CDCl}_{3}\right) \delta 7.81-6.91(\mathrm{~m}, 25 \mathrm{H}, \mathrm{Ph}), 4.78(\mathrm{~s}, 5 \mathrm{H}, \mathrm{Cp})$, 3.73, $3.06\left(2 \mathrm{~m}, 4 \mathrm{H}, \mathrm{PCH}_{2} \mathrm{CH}_{2} \mathrm{P}\right), 2.51(\mathrm{~s}, 1 \mathrm{H}, \mathrm{CHCN})$; ${ }^{31 \mathrm{P} \mathrm{NMR}}$ $\left(\mathrm{CDCl}_{3}\right) \delta 105.4(\mathrm{~s}), 103.9$ (s); MS (FAB, m/z) $729\left(\mathrm{M}^{+}\right), 701$ $\left(\mathrm{M}^{+}-\mathrm{CO}\right)$. Anal. Calcd for $\mathrm{C}_{42} \mathrm{H}_{35} \mathrm{NOP}_{2} \mathrm{Mo:} \mathrm{C}, 69.33 ; \mathrm{H}, 4.85$; $\mathrm{N}, 1.93$. Found: C, 69.97; $\mathrm{H}, 5.35, \mathrm{~N}, 2.64$.

X-ray Structure Determination of $\mathbf{5}$ and 6. Yellow crystals of $\mathbf{5}$ suitable for $\mathbf{X}$-ray diffraction study were grown directly from a mixture of hexane/ $\mathrm{CH}_{2} \mathrm{Cl}_{2}$. A single crystal of dimensions $0.30 \times 0.35 \times 0.40 \mathrm{~mm}^{3}$ was glued to a glass fiber and mounted on an Nonius CAD-4 diffractometer. Data were collected and processed, and crystallographic computations were carried out using the NRCC structure determination package. ${ }^{12}$ The structure was solved using direct methods ${ }^{13}$ and was refined on intensities of 4949 reflections to give $R=$ $0.034, \mathrm{R}_{\mathrm{w}}=0.037(\mathrm{I}>2 \sigma(\mathrm{I}))$. For $\mathbf{6}$, a single crystal of dimensions $0.20 \times 0.25 \times 0.35 \mathrm{~mm}^{3}$ was mounted on a glass fi ber with epoxy. Data were collected at room temperature on a Siemens SMART CCD area detector system employing a 3 $\mathrm{kW}$ sealed tube X-ray source operating at $1.5 \mathrm{~kW}$. The total data collection was approximately $6 \mathrm{~h}$, yielding 7071 independent data after integration using SAINT. ${ }^{14}$ Unit cell parameters were determined from the least-squares refinement of three-dimensional centroids of unique reflections. Data were corrected for absorption with the SADABS program. ${ }^{15}$ The space group was assigned as $\mathrm{P} \overline{1}$, and the structure was solved and refined using direct methods included in the SHELXTL package. ${ }^{16}$ In the final model, non-hydrogen atoms were refined anisotropically, with hydrogen atoms included in idealized locations. The structure was refined to $\mathrm{R} 1=0.0411$ and $\mathrm{wR} 2$ $=0.1386$ for $\mathrm{I}>2 \sigma(\mathrm{I})$ and to $\mathrm{R} 1=0.0451$ and $\mathrm{wR} 2=0.1434$ for all data. ${ }^{17}$ Crystal and intensity collection data for $\mathbf{5}$ and $\mathbf{6}$ are given in Table 3, and fractional coordinates and thermal parameters are given in the Supporting Information.

Acknowledgment. Financial support from the $\mathrm{Na}$ tional Science Council, Taiwan, is gratefully acknowledged.

Supporting Information Available: Details of the structural determination for complexes $\mathbf{5}$ and $\mathbf{6}$, including crystal and intensity collection data, positional and anisotropic thermal parameters, and all of the bond distances and angles. This material is available free of charge via the Internet at http://pubs.acs.org.

OM9907167

(12) Gabe, E. J .; Lee, F. L.; Lepage, Y. In Crystall ographic Computing 3; Sheldrick, G. M., Kruger, C., Goddard, R., Eds.; Clarendon Press: Oxford, England, 1985; p 167.

(13) Sheldrick, G. M. SHELXS-86, Program for Crystal Structure Solution; University of Gottingen: Gottingen, Germany, 1986

(14) SAINT (Siemens Area Detector Integration) program; Siemens Analytical X-ray: Madison, WI, 1995

(15) The SADABS program is based on the method of Blessing; see: Blessing, R. H. Acta Crystallogr., Sect. A 1995, 51, 33.

(16) SHELXTL: Structure Analysis Program, version 5.04; Siemens Industrial Automation Inc.: Madison, WI, 1995.

(17) $G O F=\left[\sum\left[w\left(F^{2}{ }_{o}-F^{2}{ }_{c}\right)^{2}\right] /(n-p)\right]^{1 / 2}$, where $n$ and $p$ denote the number of data and parameters. $\left.\mathrm{R} 1=\left(\sum|| \mathrm{F}_{\mathrm{o}}|-| \mathrm{F}_{\mathrm{c}} \mid\right)\right) / \sum\left|\mathrm{F}_{\mathrm{o}}\right|, \mathrm{wR} 2=[\Sigma-$ $\left[\mathrm{W}\left(\mathrm{F}^{2}{ }_{0}-\mathrm{F}^{2} \mathrm{c}^{2}\right] / \Sigma\left[\mathrm{W}\left(\mathrm{F}^{2}{ }_{0}\right)^{2}\right]\right]^{1 / 2}$, where $\mathrm{W}=1 /\left[\sigma^{2}\left(\mathrm{~F}^{2}{ }_{0}\right)+(\mathrm{aP})^{2}+\mathrm{bP}\right]$ and $\mathrm{P}$ $=\left[\left(\max ; 0, \mathrm{~F}^{2} \mathrm{o}\right)+2 \mathrm{~F}^{2} \mathrm{c}\right] / 3$. 